\title{
Cadherin EGF LAG Seven-Pass G-Type Receptor 1
}

National Cancer Institute

\section{Source}

National Cancer Institute. Cadherin EGF LAG Seven-Pass G-Type Receptor 1. NCI

Thesaurus. Code C25905.

Cadherin EGF LAG seven-pass G-type receptor 1 (3014 aa, $~ 329 \mathrm{kDa}$ ) is encoded by the human CELSR1 gene. This protein is involved in cell-cell signaling and adhesion. 